\title{
RESEARCH ON SOME PLANT SPECIES CONTAINING ESSENTIAL OILS PERFORMED AT UNIVERSITY OF MEDICINE AND PHARMACY „IULIU HAŢIEGANU" CLUJ-NAPOCA
}

\author{
Mircea TAMAŞ ${ }^{1}$, Georgeta BALICA ${ }^{2}$, Cristina ŞTEFÁNESCU ${ }^{2}$ \\ 12 Drapelului st, RO-400475 Cluj-Napoca, Romania \\ ${ }^{2}$ Department of Pharmaceutical Botany, University of Medicine and Pharmacy "Iuliu Haţieganu" \\ 23 Gh. Marinescu st., RO-400337 Cluj-Napoca, Romania \\ e-mail: bgeorgeta@umfcluj.ro
}

\begin{abstract}
The present article offers a synthesis of original research performed at the department of Pharmaceutical botany of „Iuliu Hațieganu” University of Medicine and Pharmacy Cluj-Napoca on 17 species and varieties of essential oil-containing plants that belong to 11 genera, all Romanian traditional medicinal, endemic or ornamental species. The essential oils were qualitatively analized and quantified by TLC and GC-MS from: Tanacetum balsamita (2 varieties), Artemisia abrotanum, Rhododendron myrtifolium, Origanum vulgare, Artemisia annua, Inula helenium, Salvia officinalis, Thuja occidentalis, Acorus calamus, Achillea (4 species) and Solidago (3 species). The chemical composition of these species belonging to the Romanian flora was established, two chemical infraspecific taxa were identified within Tanacetum balsamita and Achillea distans, and toxic compounds from essential oils ( $\beta$ asarone, thujone) were quantified.
\end{abstract}

Key words: essential oils, medicinal plants, chemical infraspecific taxa.

\section{Introduction}

The essential oils are odorant secondary plant metabolites produced and stored by specialized cells and tissues. Compared to fatty oils that leave traces on paper or other substrates, the essential oils evaporate without trace. They represent complex mixtures of numerous substances of great diversity, a few thousand being identified up to the present in different species. The main constituents are mono- and sesquiterpenes, aromatic compounds and phenyl-propanes. The terpenes can be hydrocarbons or their oxygen-containing derivatives (oxides, alcohols, aldehydes, ketons, acides, ethers, esters) or glycosides. The main plant families containing essential oils are in the pinophytes and magnoliophytes: Pinaceae, Cupressaceae, Myrtaceae, Lauraceae, Apiaceae, Rutaceae, Lamiaceae, Asteraceae, Zingiberaceae. In order to extract the essential oils from fresh or dried plant material, several techniques are available: extraction using fatty substances or organic solvents, cold-pressed extraction, steam and hydro-distillation, or more recently ,green' methods such as ultrasound-assisted extraction, microwave-assisted extraction, sub- and supercritical fluid extraction, pressurized fluid extraction, pulsed electric fields, high voltage electrical discharges. In plants, their role seems to be protection against pathogens, or repellents, as well as the inter-relation with biological agents: attracting pollinators or as alelopathic agents. The essential oils are also important for therapy, their main pharmacological properties being: antimicrobial, antiviral, antifungal, insecticidal, repellent, anti-protozoal, 
antioxidant, anti-inflammatory, antimutagenic, eupeptic, carminative, choleretic and vulnerary. One of the mainstream alternative and complementary therapies at the present day is aromatherapy, which uses essential oils as the main therapeutical agents to treat several illnesses. Various applications can also be found in the agricultural, cosmetic and food industries $[2,6,9,13,14,23,25,27,29,48]$.

\section{Objectives}

During the period 1971-2014, several researches on plants containing essential oils have been performed by the first author and various collaborators at the department of Pharmaceutical Botany of the Faculty of Pharmacy of „Iuliu Haţieganu” University of Medicine and Pharmacy, Cluj-Napoca, their results being published in different journals. Some of them were continued in PhD studies or for practical applications. The present article aims to present a synthesis of these researches, some of them representing original studies on traditional Romanian medicinal plants, emphasizing their chemical composition and biological action. The species described are: Tanacetum balsamita L., Artemisia abrotanum L., A.annua L., Inula helenium L., Achillea spp. and Solidago spp. (Asteraceae family), Origanum vulgare L. and Salvia officinalis L. (Lamiaceae), Rhododendron myrtifolium Schott et Kotschy (Ericaceae), Acorus calamus L. (Araceae), and Thuja occidentalis L. (Cupressaceae). The researches concerning each species are presented chronologically.

\section{Tanacetum balsamita L. syn. Chrysanthemum balsamita (L.) Baill. (Asteraceae)}

The species is known as alecost, bible leaf, camphor plant, costmary, mint geranium, Patagonian mint, or women's leaf [76]. It has two subspecies: Tanacetum balsamita L. var. tanacetoides Boiss. (syn. C. balsamita var. tanacetoides Boiss.), having yellow button-shaped inflorescences (capitula) formed of yellow tubular florets, and T. balsamita L. var. balsamitoides P.D. Sell (syn. C. balsamita var. balsamita) that has daisy-like white inflorescences with yellow centres, formed by peripheral white ligulate florets and central yellow tubular florets. Some authors even consider the latter to be a distinct species, Tanacetum balsamitoides Sch. Bip. $[53,63,76]$. Both are cultivated in Romanian gardens for ornamental and aromatic purposes, more often the first variety [63].

The researches performed at The Faculty of Pharmacy in Cluj-Napoca concentrated on the essential oil, as well as on hydro-alcoholic extracts from the two varieties.

The yield of essential oil extracted from the aerial parts during the flowering period was $0.6-1.3 \%$ (ml/100g dried plant material) [47]. The main constituent of essential oils extracted from both varieties was identified by gas chromatography: carvone (55-60\%) in the first and camphor $(85-90 \%)$ in the second. These results demonstrated that these two morphological varieties correspond to two chemical infraspecific taxa: C. balsamita var. tanacetoides chvar. carvone and C. balsamita var. balsamita, chvar. camphora [60]. Correlated research established the number of chromosomes in the meristem obtained from young roots formed on rhizomes during the spring. This number was $2 \mathrm{n}=54$ (hexaploid) for $C$. balsamita var. tanacetoides and $2 \mathrm{n}=18$ (diploid) for $C$. balsamita var. balsamita [57].

The two varieties were cultivated at Bod by SC Nivea Brașov, the essential oil and the hydro-alcoholic extracts being used in Tonorelaxin medicinal and cosmetic products [33,34]. The essential oil demonstrated antimicrobial, antifungal and muscle relaxing action $[34,56,63]$. In rats, 
the hydroalcoholic extract demonstrated hepatoprotective action against intoxication with carbon tetracloride and ethanol [50]. The methods for obtaining the essential oil and the hydro-alcoholic extracts were subject to official patents $[33,69]$. The two varieties were the subjects of two $\mathrm{PhD}$ theses [26,32].

\section{Artemisia abrotanum L. (Asteraceae)}

Commonly known as southernwood [78], this species originates from southern Europe and is frequently cultivated as an aromatic and ornamental plant [12]. For culture purposes, the plant can be propagated by stem cuttings that easily form roots [51].

The above-mentioned studies led to the quantification of the essential oil from the leaves of the plant: $0.51 \%(\mathrm{ml} / 100 \mathrm{~g})$ in fresh plant material and $2.1 \%(\mathrm{ml} / 100 \mathrm{~g})$ in dried [46]. The main constituent of the essential oil was also identified as eucalyptol (1,8-cineole) [46], confirmed by further researches [73]. The essential oil was enriched in eucalyptol through fractioned distillation, its content rising from $29.6 \%$ to $76.7 \%$, this resource being considered the richest in eucalyptol in the Romanian flora [5]. The studies concerning the biological activity of the essential oil identified its antimicrobial and antifungal properties [56].

The species was analysed in $\mathrm{PhD}$ studies concerning essential oil-containing plants [4].

\section{Rhododendron myrtifolium Schott et Kotschy syn. Rh. kotschy Simonk. (Ericaceae)}

This rhododendron is a small shrub that occurs in the South and East Carpathians, extending to the southern part of the Balkan Peninsula (Bulgarian Rhodope). The plant only grows at higher altitudes and the area of occupancy is less than $500 \mathrm{~km}^{2}$. At present the species is highly fragmented, several subpopulations being lost, among the main threats being cited grazing and climate change. The species is listed as Endangered globally [12,72].

Tamas and Ciupe (1974) identified brown peltate glands, structures where the essential oil was located, on the lower epidermis of the leaves, using Sudan III reagent (by the red-orange colouration) [58]. The same authors identified a $0.75 \%(\mathrm{ml} / 100 \mathrm{~g})$ yield of essential oils in the dried leaves [58]. Further studies performed by thin layer chromatography (TLC) and gaschromatography (GC) identified as main constituents of the essential oil $\alpha$ and $\beta$-pinen, borneol, linalool, and through gas-chromatography and mass selective detection (GC-MSD) were quantified the $\alpha$-pinen $(42.42 \%)$, $\beta$-selinen $(27.66 \%), \beta$-pinen $(5.13 \%)(21,22)$. In vitro tests concerning the biological action of the essential oil showed reduced antimicrobial and antifungal activity [56]. The studies previously mentioned represent the first researches on the indigenous species Rh. myrtifolium.

\section{Origanum vulgare L. (Lamiaceae)}

Oregano is a widespread plant species which is native to the Mediterranean, Euro-Siberian and Irano-Turanian regions. It is a well-known medicinal plant indicated to relieve respiratory pathologies such as convulsive cough and colds, as well as skin diseases or digestive disorders. It has also been used from ancient times to flavour traditional dishes [10,11,31].

Even though the Romanian literature on medicinal plants mentions a high content $(70 \%)$ of phenols (thymol, carvacrol) in the essential oil, by citing data obtained from other Origanum species or different $O$. vulgare varieties from southern Europe [9,10,11,24], the amount of phenols in the essential oil from the indigenous species is very reduced or even absent [68]. These results 
were confirmed experimentally by Nurzinska-Wierdak et al. (2012), who similarly indicated that the essential oil of $O$. vulgare in Poland does not contain phenolic derivatives [39].

Other comparative studies (GC-MS) with the essential oil of Thymus vulgaris, and that obtained from a commercial sample of ,Oregano' spice, identified respectively $70 \%$ and $64 \%$ phenolic compounds in these two samples, whereas the main constituents in the indigenous species were sabinene, $\beta$-caryophylene, trans- $\beta$-ocimene, germacrene-D and $\partial$-4-carene [64].

\section{Artemisia annua L. (Asteraceae)}

This species is commonly known as annual wormwood, sweet Annie or sweet wormwood [78] and is traditionally used in our country for its insecticidal properties. It contains, besides the essential oil, a sesquiterpene lactone, namely artemisinin, that is proven to have antimalarial properties superior to those of synthetic chloroquine [6,7,9,24,27]. These properties are well known, the species being traditionally used throughout Asia and Africa for the treatment of malaria, which led Chinese researchers to the isolation and characterization of artemisinin, for which they were awarded the Nobel Prize for Medicine or Physiology in 2015 [30,79]. We should note that artemisinin is not volatile, its extraction being performed by various techniques other than steam distillation [6]. Recent studies indicate that the plant seems also to have promising antitumour activities [30].

Researches carried out by Popescu, Tămaş and Tibori (1980), the first on the essential oil of this indigenous species, indicated 1.82-2.28\% essential oil in the dried plant material, the identified constituents of this plant being artemisiacetone, $\beta$-caryophyllen, linalyl acetate, thujone, camphene, borneol, and $\beta$-pinene [43].

Other Romanian studies on the species indicated the evolution of artemisinin during the vegetative period using a high performance liquid chromatography technique coupled with massspectrometry (HPLC-MS) [28], and the increase in plant biomass through biotechnology (17).

\section{Inula helenium L. (Asteraceae)}

Elecampane, called also horse-heal or elfdock, is a widespread plant species in the sunflower family Asteraceae. In some European pharmacopoeias, the roots (Inulae radix) are officially listed as diuretic, diaphoretic, expectorant and antihelminthic. The effect on Mycobacterium tuberculosis is also mentioned in the literature [10,11,27,75]. It has been demonstrated that the essential oil and extracts from Inula helenium roots are rich in sesquiterpene lactones, mainly alantolactone and isoalantolactone [74]. A specific characteristic of the essential oil from the elecampane root is its semi-solid consistency at room temperature $\left(30^{\circ} \mathrm{C}\right)$, as compared to other volatile oils that are in liquid state at this temperature.

In order to avoid possible adulterations of the Inula helenium root (with the species Telekia speciosa or Atropa belladonna) Tămaş et al. have developed a TLC technique for highlighting the presence of alantolactone in the root extracts. Also, they have isolated the essential oil with a yield of 2.82\% (62.66). Nan et al. (2010) have isolated alantolactone from roots by specific extraction and then investigated it by TLC and IR spectroscopy. GC-MS analysis of the essential oil revealed the presence of alantolactone (63\%) and isoalantolactone (36.2\%), these representing $99.2 \%$ of the isolated essential oil [36,37]. 


\section{Salvia officinalis L. (Lamiaceae)}

The species is commonly known as sage, garden sage or common sage, being a medicinal, ornamental and aromatic plant known from ancient times for its therapeutic properties ("Qur morietur homo, qui salvia crescit in horto") $[9,10,11,27]$. This species was listed in the Romanian Pharmacopoeia, $8^{\text {th }}$ ed. (1965) [18]. Sage is largely used as a savoury food flavouring, either as dried leaves or essential oil. Leaves of S. officinalis are used for the treatment of disorders of the oral cavity, mild dyspepsia (such as heartburn and bloating) and gastro-intestinal atony. Also, $S$. officinalis has been used to treat excessive sweating, age-related cognitive disorders, and throat or skin inflammations. [10,11,13,22,59]. The essential oil possesses carminative, antispasmodic, antiseptic, astringent and antihydrotic properties [1].

Tămaş et al. reported a content of $0.85 \%$ essential oil in the vegetal product Salviae folium. The volatile oil content has been analyzed by TLC and GC-MS. The GC-MS revealed the presence of $\alpha$-thujone and $\beta$-thujone (34.04\%), camphor (26.53\%), eucalyptol (13.68\%), borneol (7.49\%), $\alpha$-pinene $(4.88 \%)$, camphene $(4.30 \%)$ and terpineole $(2.34 \%)$ [59]. An original product, Salviaclim, was produced and used for the treatment of the climacteric syndrome [70].

\section{Thuja occidentalis L. (Cupressaceae)}

This tree from eastern North America is commonly known as Arbor vitae or white cedar, and is grown in Europe as an ornamental. The fresh plant contains essential oil, the main constituent being thujone, a toxic compound $[3,38]$. The tincture of young branchlets and the essential oil of leaves are used in pharmaceutical products for the treatment of warts and papillomas [24,27], for example Verucolisin (the tincture obtained from fresh material) $[8,54]$ and Herbaclear (the essential oil) [77].

The studies performed at UMF Cluj-Napoca measured the monthly variation in the yield of the essential oil of the branchlets (Thuja sumitates), a maximum being found in dried material during August $(0.90 \mathrm{ml} / 100 \mathrm{~g})$. The identification of the components of the essential oil was realized by TLC and GC-MS, and revealed the existence of 23 components; the most important were thujone (53.73\%), isothujone (13.47\%), fenchone $(9.31 \%)$ and sequiterpene compounds $(8.72 \%)[61]$.

\section{Acorus calamus L. (Acoraceae)}

The sweet flag or calamus is a semi-aquatic herb growing in shallow water or in a very moist loamy soil. In Romania, two local variants of $A$. calamus, 'De Bega' (from 1980) and 'Ursula' (from 2003) are cultivated for medicinal purposes [35]. The culture of the species was also initiated in Mureș County. Its rhizome contains essential oils, saponins and flavonoids [49]. The plant exhibits polyploidy, and, depending on the $\beta$-asarone content of the essential oil, several chemical varieties correlated with the degree of ploidy are known [65]. The rhizome powder was used as a bitter tonic to cure anorexia, dyspepsia and duodenal ulcer (Ulcerotrat) [52]. The essential oil has been used in alcoholic beverages, as a fragrant essence in perfumes and oils, and for insecticidal properties [45]. Due to the toxicity (carcinogen) of $\beta$-asarone, this main component of the essential oil is limited to a concentration up to $0.01 \%$ [55].

The first studies on A. calamus from Romania were performed on the commercial product (Calami radix from Plafar) and indicated a content of $2.29 \%$ essential oil ( $\mathrm{ml} / 100 \mathrm{~g}$ ). TLC densitometric determination and UV-spectrometry reported that $\beta$-asarone is the major constituent 
of both the essential oil and hydro-alcoholic extract. GC-MS analysis of essential oil samples resulted in the identification and quantification of 39 constituents, among which $\beta$-asarone represents $10.95 \%$, and this value corresponds to the triploid varieties grown in Europe. In-depth research was carried out by Oprean et al. (1998) to identify the isomers and minor components [40-42].

\section{Achillea sp. (Asteraceae)}

The genus Achillea has a complex taxonomy. Studies on the composition of the essential oils of Achillea spp. have been used as an additional characteristic of inter- and infraspecific differentiation. Achillea millefolium L., known as milfoil or common yarrow is considered to be one of the oldest medicinal plants, the vegetal medicinal products used being Millefolii herba (aerial part) and Millefolii flos (inflorescences) [71]. The Romanian Pharmacopoeia, $10^{\text {th }}$ ed., lists the officinal product Millefolii flos with an essential oil content of minimum $0.2 \%$ and the Romanian Pharmacopoeia $8^{\text {th }}$ ed. designates an azulene content of at least $12 \%[18,19]$.

The studies performed by Tămaş and Popovici investigated the essential oils from the officinal species, as well as the essential oils from the species Achillea stricta Gremli (syn. A. distans Waldst. \& Kit. ex Willd. subsp. stricta (Gremli) Janch.), A. nobilis L. subsp. neilrichii (A. Kern.) Velen, and those from two subspecies of Achillea distans: A. distans subsp. distans and A. distans subsp. alpina (Rochel.) Soó., harvested from the Rodna mountains in the Eastern Carpathians. A. distans subsp. distans has white ray florets and A. distans subsp. alpina (Rochel) Soó has rose-pink ray florets [67]. The aim of these studies was to determine the essential oil content in the inflorescences of the four species, and the azulene content in the isolated essential oil. The essential oil of the inflorescences yielded $0.40 \%$ in A. millefolium, $0.24 \%$ in A. stricta, $0.27 \%$ in $A$. nobilis subsp. neilrichii, $0.40 \%$ in A. distans subsp. distans and $0.25 \%$ in $A$. distans subsp. alpina. The content of azulenes in the essential oil was $25.26 \%$ for $A$. millefolium and $2.41 \%$ for $A$. stricta, while in the other species the azulenes are not present [44]. Therefore, the species $A$. nobilis, $A$. distans and $A$. stricta do not correspond to the standards of the Romanian Pharmacopoeia and they cannot substitute for the officinal species A. millefolium.

By GC-MS comparative analysis of essential oils from the two subspecies of $A$. distans, it was observed that two infraspecific taxa (chemotypes) with different chemical composition can be distinguished. In the essential oil of $A$. distans subsp. distans, the main constituents were $\alpha$-thujone (33.31\%) and $\beta$-thujone (25.52\%). In the essential oil of $A$. distans subsp. alpina, the thujone is absent and the main constituents were eucalyptol (20.19\%), sabinene $(6.37 \%)$ and camphor (4.94\%) [67].

\section{Solidago spp. (Asteraceae)}

Three species of the genus Solidago have been studied: Solidago virgaurea L. subsp. virgaurea, S. canadensis L. and S. gigantea subsp. serotina (Kunze) McNeill (syn. S. serrotina Ait.). The herbal product of $S$. virgaurea (Virgaureae herba) has been traditionally used to treat the urinary tract, nephrolithiasis and the prostate $[9,10,11,24]$.

$S$. virgaurea subsp. virgaurea, goldenrod, is an indigenous perennial herb with a vertical, cylindrical knotted rhizome, usually without stolons. The yellow flowers are grouped in capitula 10-15 mm across, arranged in long racemes. The ligules of the ray florets are 4-9 mm width. $S$. canadensis L., commonly named Canadian goldenrod, is a rhizomatous, upright herbaceous 
perennial plant with numerous stolons and with capitula forming compact erect panicles. The ligules of the ray florets are at most $4 \mathrm{~mm}$ in width. S. gigantea subsp. serotina (Kunze) McNeill (syn. S. serrotina Ait.), tall goldenrod or giant goldenrod, is a herbaceous perennial with an erect rhizome and an inflorescence arranged in smaller, compact and pendent panicles. Also, the ligules of the ray florets are at most $4 \mathrm{~mm}$ in width. The last two species of Solidago are decorative, ornamental plants, native to North America that have become adventive or sub-spontaneous plants in Romania and elsewhere [15].

We found that the essential oil yielded respectively $0.40 \%$ in $S$. virgaurea, $0.96 \%$ in $S$. canadensis and $0.16 \%$ in $S$. gigantea. The chemical composition of the essential oil and the proportion of common compounds are distinct for the three species. Thus, the major compounds for S. virgaurea are myrcene (46.30\%), $\alpha$-pinene $(13.27 \%), \alpha$-phellandrene $(12.57 \%)$ and $p$ cymene $(9.27 \%)$; for $S$. canadensis they are $\alpha$-pinene (37.80\%), limonene (24.80\%), germacrene$\mathrm{D}(14.08 \%)$ and myrcene $(8.74 \%)$; and for $S$. gigantea they are aristolone (36.73\%), germacreneD (7.5\%), sathulenol (6.44\%), bornyl acetate $(6.04 \%)$ and gurjunene $(5.22 \%)[15,16]$. In practice, the essential oil of $S$. canadensis is important due this high content of germacrene-D, valued for adding aromatic flavour to same alcoholic beverages.

\section{Conclusions}

1. This review summarizes the original researches on essential oils from medicinal, aromatic and ornamental plants of the Romanian flora.

2. By TLC and GC-MS methods the essential oils from seventeen species and varieties, belonging to eleven genera, were qualitatively and quantitatively analyzed.

3. Based on the composition of the essential oils, two infraspecific taxa in Tanacetum balsamita and Achillea distans were identified.

4. The content of the essential oils and their chemical composition were specified for the first time for Artemisia abrotanum and Rhododendron myrtifolium.

5. In some of the essential oils analyzed, the content of toxic compounds ( $\beta$-asarone, thujone) was determined.

6. Contrary to previous data reported up until now, it was specified that the essential oil of Origanum vulgare from the Romanian flora does not contain thymol.

7. Some essential oils were tested for antimicrobial and antifungal effects. Also, the possible use of these essential oils in medicinal and cosmetic products was evaluated.

\section{REFERENCES}

1. Ahl, H. S-A., Hussein, M.S., Gendy, A.S.H., Tkachenko, K.G., 2015, Quality of Sage (Salvia officinalis L.) Essential Oil Grown in Egypt, International Journal of Plant Research, 1(4): 119-123.

2. Ali, B., Al-Wabel, N.A., Shams, S., Ahamad, A., Khan, S.A., Anwar, F., 2015, Essential Oils Used in Aromatherapy: A Systemic Review, Asian Pacific Journal of Tropical Biomedicine, 5: 601-611, https://doi.org/10.1016/j.apjtb.2015.05.007.

3. Alves, L.D.S., Figueirêdo, C.B.M., Silva, C.C.A.R., Marques, G.S., Ferreira, P.A., Soares, M.F.R., Silva, R.M.F., Rolim-Neto, P.J., 2014, Thuja occidentalis L. (Cupressaceae): Review of botanical, phyto-chemical, pharmacological and toxicological aspects, International Journal of Pharmaceutical Sciences and Research, 5(4): 1163-1177. 
4. Bâtiu, I., 1995, Contribuții la tehnologia de separare și valorificare superioară a uleiurilor volatile, Teză de doctorat, Univ. Babeș-Bolyai Cluj Napoca.

5. Bâtiu, I., Mărculescu, A., Faur, M., Tămaş, M., 1990, Cercetări privind înnobilarea în eucaliptol a unui ulei volatil indigen. In: „Realizări și Perspective în Cercetarea Biochimică Românească”, Filiala Academiei Române Cluj-Napoca: 38-45.

6. Bruneton, J., 1993, Pharmacognosie, Phytochimie, Plantes medicinales, $2^{\mathrm{e}}$ ed., TEC-DOC, Londres-Paris-New York.

7. Butnar, S., Csedo, C., Eșianu, S., 1996, Artemisia annua L. - tradiție și experiență în tratamentul malariei, Acta Phytotherapeutica Romanica, 3(1-2): 8-11.

8. Catalog de produse, 1989, Institutul de Medicină și Farmacie Cluj-Napoca, Laboratorul de Microproducție Farmacie.

9. Ciulei, I., Grigorescu, Em., Stănescu, U., 1993, Plante medicinale, Fitochimie și Fitoterapie, vol. II. Ed. Medicală, București.

10. Coiciu, Evd., Racz, G., 1962, Plante medicinale și aromatice, Edit. Academiei RPR, București.

11. Crăciun, F., Bojor, O., Alexan, M., 1977, Farmacia Naturii, vol I, II, Ed. Ceres, București.

12. Cristea, V., 2014, Plante vasculare: diversitate, sistematică, ecologie şi importantăa, Presa Universitară Clujeană, Cluj-Napoca.

13. Cucu, V., 1975, Farmacognozie, vol. II, Editura IMF, Cluj Napoca.

14. De Souza M.A., da Silva L., Macêdo M.J.F., Lacerda-Neto L.J., dos Santos M.A.C., Coutinho H.D.M., Cunha F.A.B., 2019, Adulticide and repellent activity of essential oils against Aedes aegypti (Diptera: Culicidae) - A review, South African Journal of Botany, 124: 160-165.

15. Dobjanschi, L., 2006, Cercetări farmacobotanice asupra unor specii vegetale indigene cu saponine triterpenice, Teză de doctorat, UMF Cluj Napoca.

16. Dobjanschi, L., Fritea, L., Patay, E.B., Tămaș, M., 2019, Comparative study of the morphological and phytochemical characterisation of Romanian Solidago species, Pakistan Journal of Pharmaceutical Sciences, 32 (4): 1571-1579.

17. Domokos, E., Jakab-Farkas, L., Darko, B., Biro-Janka, B, Mara, G., Balog, A., 2018, Increase in Artemisia аппиа Plant Biomass, Artemisinin content and Guaiacol Peroxidase using the Arbuscular Mycorrhizal Fungus Rhizophagus irregularis, Frontiers in Plant Science, 9: 478.

18. Farmacopeea Română $8^{\text {ed. }}$. Supl., 1968. Editura Medicală, București.

19. Farmacopeea Română $10^{\text {ed }}$., 1993. Editura Medicală, București.

20. Georgescu, C., 2000, Contribuții la chimia florei montane din România. Teză de doctorat, Univ. Babeș-Bolyai Cluj Napoca.

21. Georgescu, C., Oprean, R., Tămaş, M., Oprean, I., 2000, Analiza GC-MSD a uleiului volatil din Rhododendron kotschyi Simk., Buletin Știinţific seria Fizică şi Chimie, Univ. Lucian Blaga Sibiu: 108-115.

22. Ghorbani, A., Esmaeilzadeh, M., 2017, Pharmacological properties of Salvia officinalis and its components, Journal of Traditional and Complementary Medicine, 7(4): 433-440.

23. Giacometti, J., Bursać Kovačević, D., Putnik, P., Gabrić, D., Bilušić, T., Krešić, G., Stulić, V., Barba, F.J., Chemat, F., Barbosa-Cánovas, G., Režek Jambrak, A., Extraction of bioactive compounds and essential oils from mediterranean herbs by conventional and green innovative techniques: A review, Food Research International 113 (2018): 245-262.

24. Grigorescu, E., Lazăr, M.I., Stănescu, U., Ciulei, I., 2001, Index fitoterapeutic, Ed. Cantes, Iași: 362-363.

25. Guignard, J.-L., 2000, Biochimie vegetale, $2^{-\mathrm{e}}$ ed., Dunard, Paris.

26. Hanganu, D., 1997. Cercetări farmacognostice asupra speciei Chrysanthemum balsamita L., Teză de doctorat, UMF Cluj-Napoca.

27. Istudor, V., 2001, Farmacognozie, Fitochimie, Fitoterapie, vol. II. Edit. Medicală, București.

28. Ivănescu, L., Vlase, L., Corciova, A., Lazăr, M.I., 2011, Artemisinin evaluation in Romanian Artemisia annua wild plants using a new HPLC/MS method, Natural Product Research 25(7): 716-722. Available from: https://doi: 10.1080/14786410903169847.

29. Kharbach, M., Marmouzi, I., El Jeml,i M., Bouklouze, A., Vander Heyden, Y., 2020, Recent advances in untargeted and targeted approaches applied in herbal-extracts and essential-oils fingerprinting - A review, Journal of Pharmaceutical and Biomedical Analysis, 177: 112849.

https://doi.org/10.1016/j.jpba.2019.112849 
30. Lang, S.J., Schmiech, M., Hafner, S., Paetz, Ch., Steinborn, C., Huber, R., El Gaafary, M.,d, Werner, K., Schmidt, Ch.Q., Syrovets, T., Simmet, T., 2019, Antitumor activity of an Artemisia annua herbal preparation and identification of active ingredients, Phytomedicine, 62, 152962.

https://doi.org/10.1016/j.phymed.2019.152962.

31. Lukas, B., Schmiderer, C., Novak, J., 2015, Essential oil diversity of European Origanum vulgare L. (Lamiaceae), Phytochemistry, 119: 32-40.

32. Mărculescu, A, 1996, Cercetări biochimice privind valorificarea principiilor active din Chrysanthemum balsamita L., Teză de doctorat, Univ. Babeș-Bolyai Cluj-Napoca.

33. Mărculescu, A., Jușcu, S., Sava, C., 1987, Ulei volatil cu camfor. Brevet de Invenție, România nr. 93.379.

34. Mărculescu, A., Neamțu, G., Tămaş, M., Curtoglu, D., 1995, Uleiurile volatile de Chrysanthemum balsamita, materii prime pentru industria farmaceutică și cosmetică, Acta Phytotherapeutica Romana, 2(1): 7-9.

35. Muntean, L.S., Tămaş, M., Muntean, S., Muntean, L., Duda, M.M., Vârban, D.I., Florian, S., 2016, Tratat de plante cultivate şi spontane, Ed. a-II-a, Ed. Risoprint Cluj-Napoca.

36. Nan, M., 2011, Studiul farmacobotanic al speciei Inula helenium L.(Asteraceae) în vederea valorificării în fitoterapie, Teză de doctorat, UMF Cluj -Napoca.

37. Nan, M.,Veres, K., Hohman, J., 2010, TLC -densitometric Determination of Sesquiterpene Lactones from Inula helenium Roots, Acta Medica Marisiensis, 56(3): 269-271.

38. Naser, B., Bodinet, C., Tegtmeier, T., Lindequist, U., 2005, Thuja occidentalis (Arbor vitae): A review of pharmaceutical, pharmacological and clinical properties. Evidence Based Complementary and Alternative Medicine, 2(1): 69-78.

39. Nurzinska-Wierdak, R., Bogucka-Kocka, A., Sowa, I., Szymczak, G., 2012, The Composition of Essential Oil from three Ecotypes of Origanum vulgare L., ssp. vulgare cultivated in Poland, Farmacia, 60(4): 571-577.

40. Oprean, R., 2000, Separarea, detecția și determinarea cantitativă a unor compuși bioactivi din uleiuri volatile prin cuplaj GC-MS, Teză de doctorat, UMF Cluj Napoca.

41. Oprean, R., Tămaș, M., Roman, L., 1998, Comparison of CG-MS and TLC Techique for asarone isomers determination, Journal of Pharmaceutical Biomedical Analysis, 18: 227-234.

42. Oprean, R., Tămaș, M., Săndulescu, R., Roman, L., 1998, Essential Oils analysis. Evaluation of the Essential Oils composition using both GC and MS Fingerprints, Journal of Pharmaceutical Biomedical Analysis, 18: 651-657.

43. Popescu, H., Tămaș, M., Tibori, G., 1980, Artemisia annua L., sursă indigenă de ulei volatil, Clujul Medical, 53(4): 331-338.

44. Popovici, M.P., 2008, Studiul farmacobotanic comparativ al unor specii de Achillea din flora spontană a României, Teză de doctorat, UMF Cluj Napoca.

45. Rădoiaș, G., Bosilcov, A., Bâtiu, I., 2005, Odorante naturale în parfumeria modernă, Casa Cărții de Știință, Cluj-Napoca.

46. Radu, A., Tămaș, M., Băncilă, E., 1973, Cercetări supra uleiului volatil de Artemisia abrotanum L. Identificarea eucaliptolului, Farmacia, 21(7): 417-424.

47. Radu, A., Tămaș, M., Ciupe, R., Tămaș-Popa, F., 1972, Chrysanthemum balsamita L., o plantă medicinală și aromatică, Clujul Medical, 45(4): 827-833.

48. Raut, J.S., Karuppayil, S.M., 2014, A Status Review on the Medicinal Properties of Essential Oils, Industrial Crops and Products, 62: 250-264.

49. Rita, W.S., Kawuri, R., Swantara, I.M.D., 2017, The essential oil contents of jeringau (Acorus calamus L.) rhizomes and their antifungal activity against Candida albicans, Journal of Health Sciences and Medicine, 1(1): 119-123.

50. Rusu, M.A., Bucur, N., Tămaş, M., 1994, Effect of Chrysanthemum balsamita L., Hidroalcoholic Extract upon the Intoxicated Liver, Fitoterapia, 65(3): 211-213.

51. Scoreico, E., Stoianov, R, 1993, Cercetări privind stabilirea modului de înmulțire la Artemisia abrotanum L., Herba Romanica, 12: 33-38.

52. Stănescu, U., Hăncianu, M., Cioancă, A., Aprotosoaie, A.M., 2014, Plante medicinale de la A la Z., Ed. Polirom, Iaşi.

53. Săvulescu, T., (ed.), 1964, Flora Republicii Populare Române, vol. IX., Editura Academiei RPR, București.

54. Tămaș, M., 1988, Soluție medicamentoasă destinată tratamentului unor afecțiuni benigne ale pielii. Brevet de Invenţie, România nr. 96.964/1988. 
55. Tămaş, M., 1999, Botanică farmaceutică, Vol III, Ed. Medicală Universitară „Iuliu Haţieganu” Cluj-Napoca.

56. Tămaș, M., Bergner, E., Radu, A., Kevorkian, F., 1975, Cercetări privind acțiunea biologică a unor uleiuri volatile, Clujul Medical, 48(2): 265-269.

57. Tămaş, M., Botez, C., Mărculescu, A., Pop, L., 1996, The Value of Caryological Studies for infraspecific Taxa of Chrysanthemum balsamita L. In 14-th Annual Meeting of Rom, Soc. For Cell Biology, Edit. Mirton Timișoara: 594-599.

58. Tămaș, M., Ciupe, R., 1974, Asupra uleiului volatil din Rhododendron kotschyi Simk., Farmacia, 22(1): 4956.

59. Tămaș, M., Făgărășan, E., Ionescu, C, 1986, Contribuții la studiul fitochimic al produsului Salviae folium, Farmacia, 34(4): 181-186.

60. Tămaș, M., Făgărășan, E., Pop, L., 1980, Taxoni chimici infraspecifici de Chrysanthemum balsamita L., Studii şi Cercetări de Biochimie, 23(2): 191-193.

61. Tămaş, M., Făgărăşan, E., Topârceanu, L., Târnoveanu, D., 1987, Contribuții la cunoaşterea compoziției chimice a speciei Thuja occidentalis L., Contrib.Bot., 22: 277-282.

62. Tămaș, M., Marinescu, I., Moț, L., 1977, Identificarea substituirilor la unele plante medicinale. Practica farmaceutică, Editura Medicală Bucureşti: 103-109.

63. Tămaș, M., Neamțu, G., Mărculescu, A., 1996, Plante medicinale și aromatice: Chrysanthemum balsamita L., Ed. Lux-Libris, Brașov.

64. Tămaş, M., Oprean, I., 2003, Precizări asupra compoziției chimice a uleiului volatil de Origanum vulgare L., Revista Medico-Chirurgicală a Societăţii de Medici şi Naturaliş̧ti Iaşi, 107(2) Supl. 1: 31-34.

65. Tămaș, M., Oprean, R., Roman, L., 1996, Identificarea și determinarea cantitativă a $\beta$-asaronei în uleiul volatil şi extracte de Acorus calamus L., Farmacia, 44(5-6): 13-21.

66. Tămaș, M., Popescu, H., 1982, Identificarea componentelor volatile din extractul fluid de Inulae radix, Farmacia, 30(3): 169-172.

67. Tămaș, M., Popovici, M., Oniga, I., Oprean, I., Coldea, Gh., 2009, Infraspecific chemical Taxa of Achillea distans Waldst. et Kit. from the Rodnei Mountains (Eastern Carpathians) Romania, Planta Medica, 75: 932.

68. Tămaș, M., Roșca, M., 1978, Cercetări asupra uleiului volatil din Origanum vulgare L., Clujul Medical, 51(2): 168-172.

69. Tămaș, M., Rusu, A.M., Bucur, N., Sâncrăian, A., Rusu, D., 1991, Procedeu de obținere a unui extract din Chrysanthemum balsamita L. Brevet de Invenție România, nr. 103.739/1991.

70. Tămaș, M., Vinți, D., Raican, D., Toader, S., 1987, Procedeu de obținere a unui sirop utilizat în tulburări de climacteriu. Brevet de Invenție România nr. 94.315/ 1987.

71. Tetenyi, P., 1970, Infraspecific Chemical Taxa of Medicinal Plants, Akad. Kiado, Budapest.

72. The IUCN Red List of Threatened Species: Rhododendron myrtifolium - published in 2017. http://dx.doi.org/10.2305/IUCN.UK.2017-3.RLTS.T83772628A86136306.en

73. Tibori, G., Tămaș, M., Bucur, H., 1981, Analiza uleiului volatil de Artemisia abrotanum L., Orientări în Fitoterapie, Sebeș-Alba, Soc. Șt. Farm. Alba: 177-179.

74. Trendafilova, A., Chanev, C., Todorova, M., 2010, Ultrasound-assisted extraction of alantolactone and isoalantolactone from Inula helenium roots, Pharmacognosy Magazine, 6(23): 234-237.

75. Yan, H., Haiming, S., Keng, G., Xiaobo, L., 2012, Chemical constituents of the roots of Inula helenium, Chemistry of Natural Compounds, 48(3): 522-524.

76. https://www.botanical-dermatology-database.info/BotDermFolder/COMP-24.html\#2602

77. http://www.herbaclear.ro/.

78. https://www.missouribotanicalgarden.org/PlantFinder/PlantFinderDetails.aspx $?$ taxonid=277395\&isprofile $=0$ $\&$.

79. https://www.nobelprize.org/prizes/medicine/2015/summary/. 


\section{CERCETĂRI ASUPRA UNOR PLANTE CU ULEIURI VOLATILE EFECTUATE LA UNIVERSITATEA DE MEDICINĂ ŞI FARMACIE „IULIU HAŢIEGANU” CLUJ-NAPOCA}

\section{(Rezumat)}

Articolul prezintă o sinteză a cercetărilor originale, efectuate la catedra de Botanică farmaceutică a Facultăţii de Farmacie, Universitatea de Medicină şi Farmacie „Iuliu Haţieganu” Cluj-Napoca, asupra a 17 specii și varietăţi de plante cu uleiuri volatile, încadrate în 11 genuri, toate fiind specii tradiționale româneşti, medicinale şi ornamentale, unele dintre acestea fiind endemice. Au fost determinate cantitativ și analizate calitativ, prin CSS și GC-MS, uleiurile volatile izolate din următoarele specii: Tanacetum balsamita (2 varietăți), Artemisia abrotanum, Rhododendron myrtifolium, Origanum vulgare, Artemisia annua, Inula helenium, Salvia officinalis, Thuja occidentalis, Acorus calamus, Achillea sp. (4 specii) și Solidago sp. (3 specii). În urma acestor cercetări s-a precizat compoziția calitativă a uleiurilor volatile din plantele provenite din flora României, au fost identificați 2 taxoni chimici infraspecifici pentru Tanacetum balsamita și Achillea distans şi s-a precizat conținutul în compuși considerați toxici din uleiurile volatile ( $\beta$-asarona, thujona). 